\title{
Clostridium populeti sp. nov., a Cellulolytic Species from a Woody-Biomass Digestor
}

\author{
R. SLEAT AND R. A. MAH* \\ Division of Environmental and Occupational Health Sciences, School of Public Health, University of California, Los \\ Angeles, California 90024
}

\begin{abstract}
A new anaerobic, mesophilic, sporeforming, cellulolytic bacterium is described. The cells of this organism stained gram negative, were motile rods, and formed terminal oval spores which swelled the cells. Colonies were irregular and opaque, with a yellow-pigmented center. Arabinose, xylose, fructose, galactose, glucose, cellobiose, maltose, sucrose, cellulose, xylan, and pectin served as substrates for growth. $\mathrm{H}_{2}, \mathrm{CO}_{2}$, acetate, butyrate, and lactate were produced during growth on cellulose or glucose. Optimal growth occurred at $35^{\circ} \mathrm{C}$ and pH 7.0. The deoxyribonucleic acid composition was $28 \mathrm{~mol} \%$ guanine plus cytosine. The name Clostridium populeti sp. nov. is proposed. The type strain is strain 743A (= ATCC 35295).
\end{abstract}

The cellulolytic bacteria from bovine rumina $(9,10)$, human colons (2), rat ceca (23), guinea pig ceca (5), horse large intestines (4), soil (29), estuarine sediments (19), freshwater sediments $(17)$, and decomposing vegetation $(18,26)$ have been extensively investigated. In contrast, very little is known about the cellulolytic bacteria in anaerobic digestor systems. However, such bacteria should be present and may enter municipal waste digestors from runoff water or from sewage containing the feces of humans and animals.

Most-probable-number determinations of cellulolytic bacteria in swine manure digestors showed that the cellulolytic and hemicellulolytic bacteria comprised less than $0.1 \%$ of the total digestor population (14). The cellulolytic bacteria in anaerobic digestors were presumed to be similar to those in rumina since nonsporeforming rods predominated $(12,20)$. However, two recent isolates show that this is not the case; thermophilic cellulolytic sporeformers were isolated from sewage sludge (24), and a cellulolytic, vibrioid, mesophilic bacterium was isolated from municipal sewage sludge (25).

We report here the isolation and characterization of an anaerobic, mesophilic, sporeforming, cellulolytic bacterium from a woody-biomass digestor. Except for Clostridium cellulovorans (30), our isolate differs from previously described digestor isolates in morphology, optimum growth temperature, substrates utilized, and fermentation products.

\section{MATERIALS AND METHODS}

Isolation. The inoculum source was a batch methanogenic fermentation of finely divided (ca. $0.8 \mathrm{~mm}$ in size) hybrid poplar wood (15) obtained from D. P. Chynoweth.

Culture methods and media. The anaerobic techniques of Hungate (12) were used throughout our experiments. The culture methods and media used have been described previously (30), except that fermentation products from $10 \mathrm{mM}$ glucose and $10 \mathrm{~g}$ of Avicel per liter were determined in medium buffered with $50 \mathrm{mM}$ HEPES ( $N$-2-hydroxyethylpiperazine- $N^{\prime}$-2-ethanesulfonic acid; Calbiochem-Behring, La Jolla, Calif.) (final $\mathrm{pH}, 7.0$ ).

Morphological, biochemical, and physiological tests. Phasecontrast photomicrographs were taken as previously described (6). Gram stain reaction, lysis by $\mathrm{KOH}$, and hydrolysis of L-alanine-4-nitroanilide were determined by the methods of Carlone et al. (3). Cell morphology, substrate utilization, temperature and $\mathrm{pH}$ optima, and growth were

\footnotetext{
* Corresponding author
}

determined as previously described (30). Starch hydrolysis, gelatin liquefaction, and catalase production were determined by the methods of Smibert and Krieg (31). A 0.1-ml inoculum from a 24-h HEPES-glucose-grown culture was used for fermentation balance determinations. For Avicel degradation, $0.5 \mathrm{ml}$ of a 72-h HEPES-Avicel-grown inoculum was used.

Analytical techniques. Culture headspace gases were analyzed by gas chromatography (1). Volatile and non-volatile fatty acids and alcohols were measured by the methods of Sleat et al. (30). Lactate was determined enzymatically with lactate dehydrogenase (lactic acid diagnostic kit; Sigma Chemical Co., St. Louis, Mo.). Formate was determined by the procedure of Lang and Lang (16); reducing sugars were determined by using the dinitrosalicylic acid reagent (22), and glucose was determined by using the Direct Glucose Test Set (Stanbio Lab Inc., San Antonio, Tex.). Residual Avicel was measured gravimetrically by the method of Weimer et al. (33).

Analysis of DNA base composition. Whole-cell deoxyribonucleic acid (DNA) was extracted and purified by the method of Marmur (21). The buoyant density of the purified DNA was determined by preparative ultracentrifugation in a cesium chloride gradient (27). DNAs from Escherichia coli strain B and Micrococcus lysodeikticus were used as controls. The DNA base ratio (guanine-plus-cytosine content) was calculated by the method of Schildkraut et al. (28).

Reagents, chemicals, and gases. All chemicals were reagent quality, except where noted. Gas mixtures were purchased from Searle Medical Products, Cucamonga, Calif. Avicel (type PH-105; lot 5150-128) was a gift from FMC Corp., Philadelphia, Pa.

\section{RESULTS AND DISCUSSION}

Strain $743 A^{T}$ ( $T=$ type strain) was strictly anaerobic, did not reduce sulfate, and formed endospores. These characteristics place it in the genus Clostridium (32). It differed significantly from other mesophilic, cellulolytic clostridia ( 7 , $11,17,19,26)$ in substrates utilized, fermentation products, morphology, and optimum growth temperature. Therefore, we propose a new species, Clostridium populeti, with the species description given below.

Description of Clostridium populeti sp. nov. Clostridium populeti (po.pu'le.ti. L. n. populetum poplar wood; L. gen. n. populeti of poplar wood) cells stain gram negative and are L-alanine-4-nitroanilide and $\mathrm{KOH}$ negative. Motile. The 

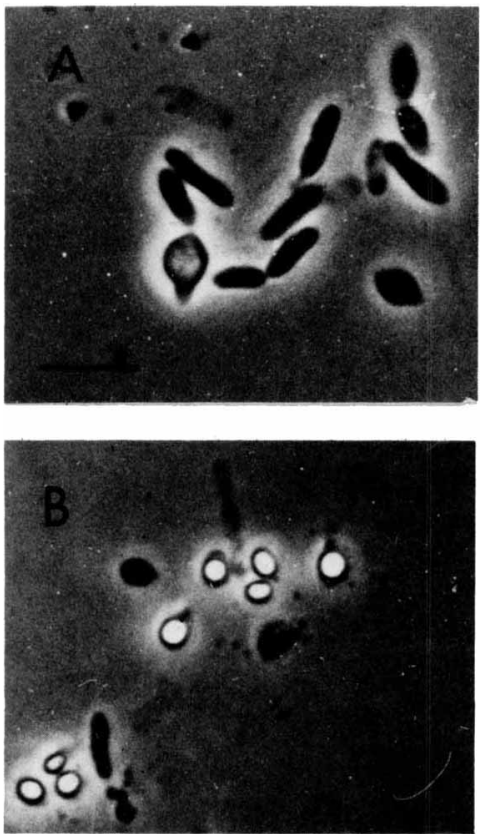

FIG. 1. Photomicrographs of a cellulose-agar-grown culture. (A) Vegatative cells and clostridium. (B) Cells with terminal, oval spores and free spores. $\mathrm{Bar}=5 \mu \mathrm{m}$.

slightly curved rod-shaped cells are 1 to $1.5 \mu \mathrm{m}$ wide and 1.7 to $3.0 \mu \mathrm{m}$ long and often occur in pairs. Oval spores form terminally and cause a marked swelling of the cells (Fig. 1). The mature spores are 1.0 to $1.2 \mu \mathrm{m}$ in diameter. Endospores are viable after heating to $80^{\circ} \mathrm{C}$ for $10 \mathrm{~min}$. Vegetative cells are resistant to sodium dodecyl sulfate but are readily lysed by lysozyme and ethylenediaminetetraacetate.

Colony characteristics. In medium solidified with $2 \%$ purified agar and containing pebble-milled cellulose, zones of clearing appear within $48 \mathrm{~h}$. Deep colonies are irregular, opaque, and yellow. The clear zone of cellulolysis can reach a diameter of $20 \mathrm{~mm}$ after prolonged incubation. The cellulose in agar roll tubes containing high numbers of cellulolytic

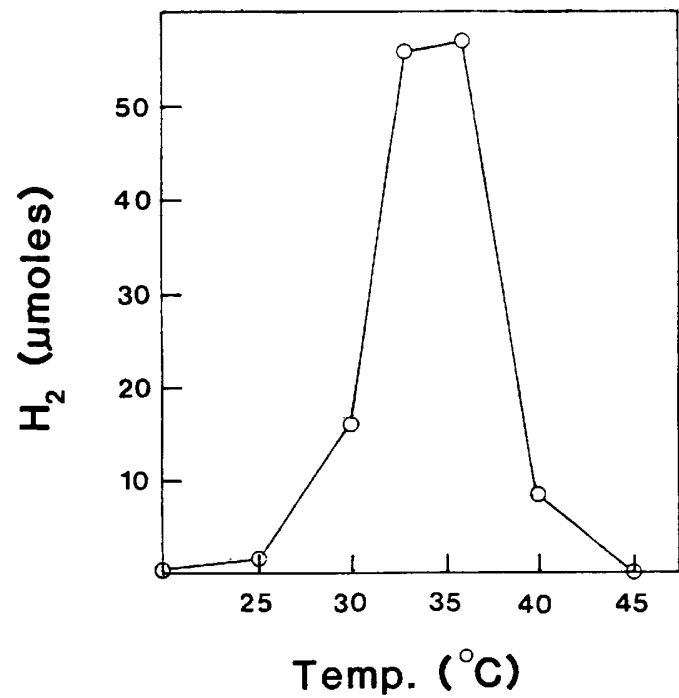

FIG. 2. Effect of temperature on $\mathrm{H}_{2}$ production by a cellobiosegrown culture. Maximal $\mathrm{H}_{2}$ production was after $17 \mathrm{~h}$ of incubation. colonies is completely hydrolyzed within 2 weeks. Surface colonies are almost invisible except for a thin opaque edge. Colonies in cellobiose-agar medium after $48 \mathrm{~h}$ of incubation are $1 \mathrm{~mm}$ in diameter, irregular, opaque, and yellow. The colonies are smooth and butyrous, becoming rhizoid with age. Colonies in pectin-agar medium are yellow; those in xylan-agar medium are orangish brown.

Nutrition and growth conditions. Rumen fluid, Trypticase peptone, and added vitamins are not required for growth. Nutritional requirements can be met by the addition of $2 \mathrm{~g}$ of yeast extract per liter, although yeast extract cannot serve as a primary substrate. The optimum temperature for growth is $35^{\circ} \mathrm{C}$, and growth occurs over a temperature range of 20 to $40^{\circ} \mathrm{C}$ (Fig. 2). No growth is observed at $15^{\circ} \mathrm{C}$ after prolonged incubation. The optimum $\mathrm{pH}$ for growth is 7.0 , and the $\mathrm{pH}$ range is 6.4 to 8.1 (Fig. 3).

Metabolic characteristics. Obligate anaerobe. Catalase negative. Sulfate not reduced. Arabinose, xylose, galactose, glucose, fructose, cellobiose, maltose, sucrose, cellulose, pectin, xylan, and gum arabic are fermented. Rhamnose, glycerol, mannose, lactose, trehalose, melezitose, erythritol, arabitol, sorbitol, lactate, and pyruvate are not fermented. Gelatin is liquefied after prolonged incubation. Starch and casein are not hydrolyzed.

Growth in liquid medium containing a soluble carbohydrate is homogeneous. Motility and endospore formation are often inhibited during growth on a soluble carbohydrate in liquid medium. Cellulose is readily fermented in medium buffered (final concentration, $50 \mathrm{mM}$ ) with PIPES [piperazine- $N, N^{\prime}$-bis(2-ethanesulfonic acid)] or HEPES organic buffer but is not fermented in the presence of morpholinepropanesulfonic acid, $N$-2-acetamido-2-aminoethanesulfonic acid, tris(hydroxymethyl)aminomethane, or $N, N$-methylenebisacrylamide-tris(hydroxymethyl)aminomethane-propane.

The products obtained from glucose after fermentation is complete and $\mathrm{H}_{2}$ production ceases are acetate $(16 \mathrm{~mol} / 100$ mol of glucose), butyrate $(72 \mathrm{~mol} / 100 \mathrm{~mol}$ of glucose $)$, lactate (50 mol/100 mol of glucose), $\mathrm{H}_{2}(98 \mathrm{~mol} / 100 \mathrm{~mol}$ of glucose),

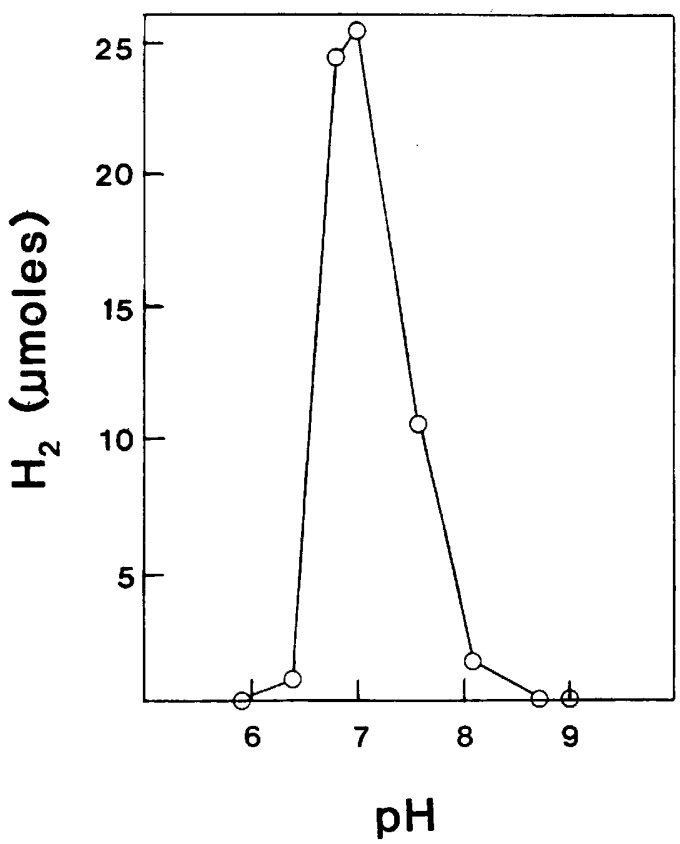

FIG. 3. Effect of $\mathrm{pH}$ on $\mathrm{H}_{2}$ production by a cellobiose-grown culture. Maximal $\mathrm{H}_{2}$ production was after $15 \mathrm{~h}$ of incubation. 


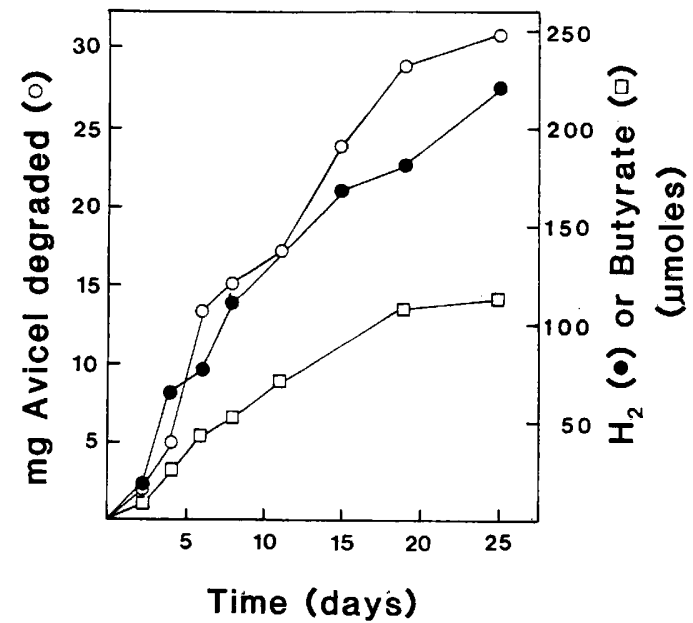

FIG. 4. Fermentation of Avicel and production of $\mathrm{H}_{2}$ and butyrate.

and $\mathrm{CO}_{2}(111 \mathrm{~mol} / 100 \mathrm{~mol}$ of glucose). These values (the means of five determinations) yield $92.5 \%$ recovery of carbon, $101 \%$ recovery of hydrogen, and give an oxidation-reduction balance of 0.92 calculated by the method of Gottschalk (8). Trace amounts of ethanol and succinate are also detected. Pyruvate and formate are not produced.

Growth on pebble-milled cellulose in liquid medium is characterized by the production of a yellow pigment which is bound to the substrate. The cellulose becomes viscous and tends to clump. The maximum rate of cellulose degradation in carbonate-buffered medium (initial pH, 7.0) is $29 \mathrm{mg} / \mathrm{liter}$ per h. $\mathrm{H}_{2}$ and butyrate production parallel Avicel degradation during growth in HEPES-buffered medium (Fig. 4). Small quantities of reducing sugars ( $4 \mathrm{mM}$ after 32 days) are produced when excess cellulose is included in the medium. The maximum rate of Avicel degradation is $8.7 \mathrm{mg} /$ liter per h.

Guanine-plus-cytosine content. The guanine-plus-cytosine content of $C$. populeti DNA is $28 \mathrm{~mol} \%$.

Source. C. populeti was isolated from a batch methanogenic fermentation of finely divided hybrid poplar wood.

Type strain. The type strain of $C$. populeti is strain 743A (= ATCC 35295).

Distinguishing characteristics. $C$. populeti is distinguished from most mesophilic, cellulolytic clostridia by its production of butyrate as a major fermentation product during cellulose degradation. The recently isolated species $C$. cellulovorans (30) also produces butyrate, but can be distinguished from $C$. populeti by its production of formate and its endospore morphology. C. cellulovorans produces central or subterminal, oblong endospores, whereas $C$. populeti produces terminal, oval endospores.

\section{ACKNOẂLEDGMENTS}

We thank D. Blank, University of California, Los Angeles, for help with the etymology of the specific epithet. Samples of a batch methanogenic fermentation of finely divided hybrid poplar wood were kindly provided by D. P. Chynoweth, Institute of Gas Technology, Chicago, Ill. We also thank Tom Ferguson, Harvey Negoro, Bernard Ollivier, and Indra Mathrani for many helpful discussions. We especially thank David R. Boone for review of the manuscript.

This work was supported by grant 5080-323-0423 from the Gas Research Institute and by research grant DE-AT03-80ER10684 from the U.S. Department of Energy.

\section{LITERATURE CITED}

1. Baresi, L., R. A. Mah, D. M. Ward, and I. R. Kaplan. 1978. Methanogenesis from acetate: enrichment studies. Appl. Environ. Microbiol. 36:186-197.

2. Betaine, H. G., B. A. Linehan, M. P. Bryant, and L. V. Holdeman. 1977. Isolation of a cellulolytic Bacteroides sp. from human feces. Appl. Environ. Microbiol. 33:1009-1010.

3: Carlone, G. M., M. J. Valadez, and M. J. Pickett. 1982. Methods for distinguishing gram-positive from gram-negative bacteria. J. Clin. Microbiol. 16:1157-1159.

4. Davies, M. E. 1964. Cellulolytic bacteria isolated from the large intestine of the horse. J. Appl. Bacteriol. 27:373-378.

5. Dehority, B. A. 1977. Cellulolytic cocci isolated from the cecum of guinea pigs (Cavia porcellus). Appl. Environ. Microbiol. 33:1278-1283.

6. Ferguson, T. J., and R. A. Mah. 1983. Isolation and characterization of an $\mathrm{H}_{2}$-oxidizing thermophilic methanogen. Appl. Environ. Microbiol. 45:265-274.

7. Giallo, J., C. Gaudin, J. P. Belaich, E. Petitdemange, and F. Caillet-Mangin. 1983. Metabolism of glucose and cellobiose by cellulolytic Clostridium sp. strain H10. Appl. Environ. Microbiol. 45:843-849.

8. Gottschalk, G. 1979. Bacterial metabolism. Springer-Verlag, New York.

9. Hobson, P. N., and R. J. Wallace. 1982. Microbial ecology and activities in the rumen. 1. Crit. Rev. Microbiol. 9:162-225.

10. Hobson, P. N., and R. J. Wallace. 1982. Microbial ecology and activities in the rumen. II. Crit. Rev. Microbiol. 9:253-320.

11. Hungate, R. E. 1944. Studies on cellulose fermentation. I. The culture and physiology of an anaerobic cellulose-digesting bacterium. J. Bacteriol. 48:499-513.

12. Hungate, R. E. 1950 . The anaerobic cellulolytic bacteria. Bacteriol. Rev. 14:1-49.

13. Hungate, R. E. 1969. A roll tube method for cultivation of strict anaerobes, p. 117-132. In J. R. Norris and D. W. Ribbons (ed.), Methods in microbiology, vol. 3B. Academic Press, Inc., New York.

14. Iannotti, E. L., J. R. Fischer, and D. M. Sievers. 1982. Characterization of bacteria from a swine manure digester. Appl. Environ. Microbiol. 43:136-143.

15. Jerger, D. E., D. A. Dolenc, and D. P. Chynoweth. 1982. Bioconversion of woody biomass as a renewable source of energy. Biotechnol. Bioeng. Symp. 12:233-248.

16. Lang, E., and H. Lang. 1972. Spezifische Farbreaktion zum Direkten der Ameisensaure. Z. Anal. Chem. 260:8-10.

17. Leschine, S. B., and E. Canale-Parola. 1983. Mesophilic cellulolytic clostridia from freshwater environments. Appl. Environ. Microbiol. 46:728-737.

18. Madden, R. H. 1983. Isolation and characterization of Clostridium stercorarium $\mathrm{sp}$. nov.; a cellulolytic thermophile. Int. J. Syst. Bacteriol. 33:837-840.

19. Madden, R. H., M. J. Bryder, and N. J. Poole. 1982. Isolation and characterization of an anaerobic, cellulolytic bacterium, Clostridium papyrosolvens sp. nov. Int. J. Syst. Bacteriol. 32:87-91.

20. Maki, L. R. 1954. Experiments on the microbiology of cellulose decomposition in a municipal sewage plant. Antonie van Leeuwenhoek J. Microbiol. Serol. 20:185-200.

21. Marmur, J. 1961. A procedure for the isolation of deoxyribonucleic acid from microorganisms. J. Mol. Biol. 3:208-218.

22. Miller, G. L., R. Blum, W. E. Glennon, and A. L. Burton. 1960 Measurement of carboxymethylcellulase activity. Anal. Biochem. 2:127-132.

23. Montgomery, L., and J. M. Macy. 1982. Characterization of rat cecum cellulolytic bacteria. Appl. Environ. Microbiol. 44:1435-1443.

24. Ng, T. K., P. J. Weimer; and J. G. Zeikus. 1977. Cellulolytic and physiological properties of Clostridium thermocellum. Arch. Microbiol. 114:1-7.

25. Patel, G. B., A. W. Khan, B. J. Agnew, and J. R. Colvin. 1980. Isolation and characterization of an anaerobic, cellulolytic microorganism, Acetivibrio cellulolyticus gen. nov., sp. nov. Int. 
J. Syst. Bacteriol. 30:179-185.

26. Petitdemange, E., F. Caillet, J. Giallo, and C. Gaudin. 1984. Clostridium cellulolyticum sp. nov., a cellulolytic, mesophilic species from decayed grass. Int. J. Syst. Bacteriol. 34:155-159.

27. Preston, J. F., and D. R. Boone. 1972. Analytical determination of the buoyant density of DNA in acrylamide gels after preparative $\mathrm{CsCl}$ gradient centrifugation. FEBS Lett. 37:321-324.

28. Schildkraut, C. L., J. Marmur, and P. Doty. 1962. Determination of the base composition of deoxyribonucleic acid from its buoyant density in CsCl. J. Mol. Biol. 4:430-443.

29. Skinner, F. A. 1960. The isolation of an anaerobic cellulose-decomposing bacterium from soil. J. Gen. Microbiol. 22:538-554.

30. Sleat, R., R. A. Mah, and R. Robinson. 1984. Isolation and characterization of an anaerobic, cellulotyic bacterium, Clos- tridium cellulovorans sp. nov. Appl. Environ. Mịcrobiol. 48:88-93.

31. Smibert, R. M., and N. R. Krieg. 1982. General characterization, p. 409-443. In P. Gerhardt (ed.), Manual of methods for general bacteriology. American Society for Microbiology, Washington, D.C.

32. Smith, L. D. S., and G. Hobbs. 1974. Genus III. Clostridium, p. 551-572. In R. E. Buchanan and N. E. Gibbons (ed.), Bergey's manual of determinative bacteriology, 8th ed. The Williams \& Wilkins Co., Baltimore.

33. Weimer, P. J., and J. G. Zeikus. 1977. Fermentation of celluose and cellobiose by Clostridium thermocellum in the absence and presence of Methanobacterium thermoautotrophicum. Appl. Environ. Microbiol, 33:289-297. 